\title{
Prevalence of Risk Factors for Coronary Artery Disease in the Brazilian State of Rio Grande do Sul
}

\author{
Iseu Gus, Airton Fischmann, Cláudio Medina \\ Porto Alegre, RS - Brazil
}

\begin{abstract}
Objective - To determine the risk factors prevalence for coronary artery disease in the State of Rio Grande do Sul, Brazil and to identify their relation with the age bracket.
\end{abstract}

Methods - We carried out an observational, crosssectional study of 1,066 adults older than 20 years in the Brazilian State of Rio Grande do Sul. We investigated the risk factors: familial antecedents, systemic arterial hypertension, high levels of cholesterol and glycemia, overweight/obesity, smoking and sedentary lifestyle. A standardized questionnaire completed at the patients' $d$ wellings by health agents were used; the data were stored in an EPI-INFO software database. The results were expressed with a $95 \%$ confidence interval.

Results - The sample composition was of $51.8 \%$ females. The risk factors prevalences were: 1) sedentary lifestyle $71.3 \%$; 2) familial antecedents: $57.3 \%$; 3) overweight/obesity (body mass index >25): $54.7 \%$; 4) smokers: $33.9 \%$; 5) hypertension: $31.6 \%$ (considering $>140$ / $90 \mathrm{mmHg}$ ) and $14.4 \%$ (considering $>160 / 95 \mathrm{mmHg}$ ); 6) high glycemia (>126 mg/dL): 7\%; 7) high cholesterol $>240 \mathrm{mg} / \mathrm{dL}$ ): $5.6 \%$.

Conclusion - The prevalence of the major risk factors for coronary artery disease in the Brazilian state of Rio Grande do Sul could be determined in a study that integrated public and private institutions.

Keywords: risk factors, epidemiology, coronary artery disease

Instituto de Cardiologia do Rio Grande do Sul/Fundação Universitária de Cardiologia - Porto Alegre

Mailing address: Iseu Gus - Serviço de Epidemiologia do IC/FUC - Av. Princesa Isabel, 395 - 90620-001 - Porto Alegre, RS, Brazil - E-mail: pesquisa@cardnet.tche.br English version by Stela Maris C. e Gandour
Cardiovascular diseases are a major public health problem not only in our environment ${ }^{1}$ but also worldwide, because they constitute the major cause of morbidity and mortality and account for the most expensive costs in medical assistance.

Due to epidemiology, we have been able to identify the determinants and the aggravating factors of heart diseases or risk factors for cardiovascular diseases, such as coronary artery disease, and their mechanism of action. With the appearance of population studies with large samples, such as the Framingham Study, we have been able to determine some risk factors more safely. This knowledge recognized as scientifically accurate has enabled an epidemiological approach aiming at the primary or secondary prevention, or both, of heart diseases.

Some major risk factors for coronary artery disease have been very well established ${ }^{2}$, such as systemic arterial hypertension, smoking, dyslipidemias, obesity, sedentary lifestyle, diabetes mellitus, and familial antecedents. Weneed to know the prevalence of these risk factors, isolated or in combination, because it is through the reduction of these risk factors and using primary and secondary prevention programs that we will achieve effectiveness in any health program.

The familial antecedents are unmodifiable and independent risk factors that, even though having already been studied $^{3}$, still require further investigation. Patients whose first-degree relatives develop early coronary artery disease have higher risks of developing coronary artery disease than the general population.

Cigarette smoking doubles the risk for coronary artery disease, $30 \%$ of which are attributed to the number of cigarettes smoked. In a study ${ }^{4,5}$ with 106,745 males in Korea, tobacco was a major and modifiable risk factor for cardiovascular disease, regardless of the serum cholesterol levels; low cholesterol levels did not provide a protective effect in those smokers. These findings are supported by those of the prospective study of the American Cancer Society, of the Nurses' Health Study, and of some meta-analyses ${ }^{6-9}$.

Coronary artery disease occurs more commonly in diabetic patients than in the general population, affecting more 
than $55 \%$ of patients. Diabetes mellitus is a major risk factor for independent cardiovascular disease, even after being adjusted for more advanced age, systemic arterial hypertension, and smoking ${ }^{10}$.

In regard to cholesterol, in a meta-analysis ${ }^{11}$ of 38 major clinical trials on primary and secondary prevention, for a $10 \%$ reduction in cholesterol levels, a $13 \%$ reduction in mortality was obtained, with a total mortality risk of $11 \%$. A wide confirmation of the risk factors for cardiovascular diseases was found in the following major studies: the West of Scotland Coronary Prevention Study (WOSCOPS) and the Air Force/Texas Coronary Atherosclerosis Prevention Study (AFCAPS/TexCAPS).

Systemic arterial hypertension is a well-established risk factor for cardiovascular disease and for congestive heart failure ${ }^{12}$. The importance of this association was well defined in the findings of the Framingham Study and of the Multiple Risk Factor Intervention Trial - MRFIT. Even though some clinical trials of systemic arterial hypertension control showed some benefits in stroke and congestive heart failure, they failed to clearly show any benefit in coronary events, mainly in the control of moderate systemic arterial hypertension ${ }^{13,14}$.

Exercise, even in moderate degrees, has a protective effect against coronary artery disease and all causes of mortality. In addition, exercise may provide a number of other benefits, such as an elevation in HDL-cholesterol levels, a reduction in systemic arterial hypertension levels, and aid in reducing body weight ${ }^{15-17}$.

Through the use of the epidemiological method of clinical investigation, prevention has increased and created concepts and lines of management for chronic degenerative diseases. The recent knowledge about the worsening factors in heart diseases in addition to the adequate disclosure and practical application of primary and secondary prevention measures will provide an actual reduction in the incidence of the cardiovascular diseases. Therefore, to determine the prevalence of the risk factors in the general population is an epidemiological requirement. Using a simple and inexpensive method, we were able to carry out a study in the State of Rio Grande do Sul, which may be a foundation or model for studies in other Brazilian states. We worked exclusively with Brazilian data that reflects the current lifestyle.

Our study extended from July 1999 to October 2000 and aimed at establishing the actual prevalence of risk factors for coronary artery disease in the Brazilian State of Rio Grande do Sul.

\section{Methods}

This was an observational, analytical, cross-sectional population-based study carried out in the Brazilian State of Rio Grande do Sul. The parameters used to calculate the sample were as follows: population size: infinite; error (absolute accuracy): $3 \%$; expected prevalence: $50 \%$ (maximum variability); confidence level: $95 \%$; calculated size of the sample: 1,066; representativity: the Brazilian State of Rio Grande do Sul.
Aiming at distributing the sample in a homogeneous manner, we chose the municipalities in which each of the 19 Regional Health Coordination Offices in the entire State of Rio Grande do Sul (SES/RS) were headquartered (fig. 1). The sample size was determined by the following formula: population of each study municipality, sum of the populations of all study municipalities x 1,066 .

A database was created using EPI6(EPI-INFO) software. The absolute and relative frequencies of the risk factors were calculated, as were the frequencies at different age brackets.

For each municipality selected, and using a map, we drew the street blocks previously numbered using a table of random numbers.

The study followed the guidelines of the Serviço de Epidemiologia da Fundação Universitária de Cardiologia/ Instituto de Cardiologia do Rio Grande do Sul (IC/FUC), and of the Seção de Controle de Agravos de Doenças CrônicoDegenerativas of the SES/RS. All health agents responsible for completing the questionnaires underwent the same training in joint meetings in the city of Porto Alegre. Arterial blood pressure measurement and blood withdrawal were performed by people trained by the SES and the Municipal Health Offices of each study municipality according to the current techniques.

Each study municipality was divided into zones, the zones into streets, the streets into every other house, and the people older than 20 years living in the randomly chosen dwellings were invited to take part in the study. If one person in the randomly chosen dwelling was absent at the time the house was visited, a new visit was later paid insisting that all people living in the chosen dwelling were interviewed. In case of refusal, the next house was chosen. All people chosen received a compliance letter, which was signed in case of agreement.

Blood pressure was measured twice during the visit, the last measurement being recorded. Weight measurement was also performed. The sphygmomanometers and scales underwent INMETRO approval; those not approved were not used.

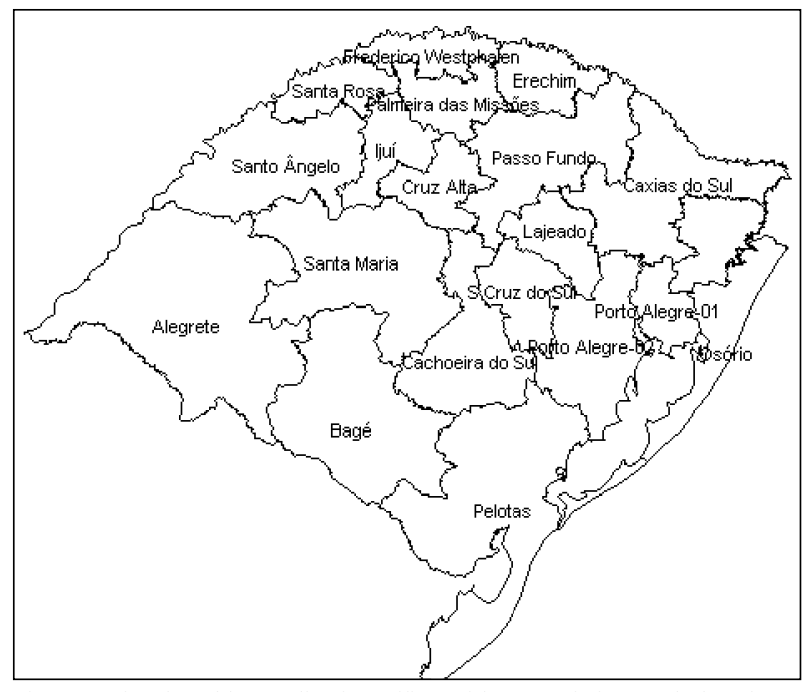

Fig. 1 - Regional Health Coordination Offices of the state of Rio Grande do Sul. 
The questionnaire comprised basic data, such as name, address, age, sex, and residence. It also comprised questions referring to possible familial antecedents of coronary artery disease, use of a certain type of medication, treatment for hypertension, hypercholesterolemia, and diabetes. For measuring total cholesterol and glucose, $5 \mathrm{~mL}$ of blood were withdrawn during fasting. The participants received their results and medical guidance whenever necessary.

The item referring to familial antecedents of angina, infarction, and ischemia comprised the following 5 possibilities: 1) absent;2) father or mother, or both, older than 60 years with coronary artery disease; 3 ) father or mother younger than 60 years with coronary artery disease; 4 ) father, mother, and sibling with coronary artery disease at any age; 5) ignored.

The body mass index was chosen to assess the risk factors of overweight and obesity. Therefore, weight and height of the interviewees were measured, and the following values were considered for classification: overweight, body mass index $>25$; obesity, body mass index $>30$.

In regard to smoking habits, the participants were asked whether they smoked and the number of cigarettes smoked per day, whether they were ex-smokers, or whether they had never smoked.

In regard to total cholesterol $(\mathrm{mg} / \mathrm{dL})$ measured during fasting, the interviewees were asked the following: 1 ) whether they were under treatment; 2) whether they knew they had high cholesterol levels, but were not under treatment; 3) whether they ignored that they had high cholesterol levels. Two ranges of total cholesterol were analyzed: from 200 to $239 \mathrm{mg} / \mathrm{dL}$ and $>240 \mathrm{mg} / \mathrm{dL}$.

In regard to glycemia, also measured during fasting, the interviewees were asked the following 4 questions: 1 ) whether they were diabetic and under treatment; 2) whether they had any diabetic relatives; 3 ) whether they knew they were diabetic, but did not receive treatment; 4) whether they did not know they were diabetic. The glycemic range from 110 to $125 \mathrm{mg} / \mathrm{dL}$ was considered borderline for diabetes, and glycemia $>126 \mathrm{mg} / \mathrm{dL}$ was considered overt diabetes.

In regard to systemic blood pressure assessment, 2 measurements were strictly recommended. The second measurement was taken 3 minutes after the first and was considered the final blood pressure of the interviewee. The interviewees were asked the following: 1) whether they were hypertensive patients under treatment; 2) whether they knew they were hypertensive, but never underwent treatment; 3) whether they gave up the treatment; 4) whether they ignored that they were hypertensive.

Sedentary lifestyle was assessed based on the physical activity of the interviewee, and was classified as follows: 1) intense professional physical activity or intense daily guided physical activity, or both;2) moderate physical activity, 5 to 7 times a week (jogging, swimming); 3) mild physical activity, twice to 4 times a week (jogging, swimming); 4) very mild physical activity; 5) physical inactivity. The participants classified as 4 or 5 were considered as having a sedentary lifestyle.

The 3 following parameters were also assessed: family income, size of the family (number of people), and visit to a public health service in the last 12 months. These parameters were requested by the SES-RS for further analyses.

All cholesterol and glucose measurements were taken by the same professionals of the Laboratório Central do Estado/Fundação Estadual de Pesquisa em Saúde (LACEN/ FEPPS) of blood samples withdrawn during fasting on the day following the first visit, when the interviewees agreed to participate in the study. The material collected was properly packed in thermal boxes with dry ice and sent to the city of Porto Alegre, according to the guidelines of the SES/ RS for shipment of material for laboratory examination.

\section{Results}

Of the 1,066 questionnaires completed, 3 had to be disregarded, leaving 1,063 questionnaires as the sample of our study. The sizes of the samples were proportional to the populations of the municipalities in which the Regional Health Coordination Offices were headquartered.

Table I shows the prevalence of the different risk factors assessed and the respective confidence intervals. The distribution of the entire sample in the different age brackets was approximately equal to that of the IBGE (Brazilian Institute of Geography and Statistics) estimate for the year 1999; an increase in the percentages of these risk factors was observed in the older age brackets.

A prevalence higher than $60 \%$ for sedentary lifestyle was observed independent of age.

In regard to the familial antecedents, only 800 interviewees were considered because 246 ignored their familial antecedents regarding coronary artery disease. The percentage of familial antecedents was $57.3 \%$.

Overweight and obesity were analyzed, a percentage of $56.3 \%$ being observed. A significant increase in the percentages was observed in the older age brackets.

In a separate analysis of smoking, we observed that males still smoke more than females do (38\% and $29.6 \%$, respectively, $\mathrm{p}=0.004$ ), and most smokers smoke more than 20 cigarettes/day ( $17.8 \%$ of the $33.9 \%)$. A significant increase in the percentage of smokers occurs up to the age of 59 years.

\begin{tabular}{|lcc|}
\hline \multicolumn{3}{|c|}{ Table I - Risk factors for ischemic heart disease in the state of } \\
Rio Grande do Sul. \\
\hline Risk factor & $\begin{array}{c}\text { Prevalence } \\
(\%)\end{array}$ & $\begin{array}{c}95 \% \text { confidence } \\
\text { interval }\end{array}$ \\
& 71,3 & $68,6-74$ \\
Sedentary lifestyle & 57,3 & $53,9-60,7$ \\
Familial antecedents & 54,7 & $51,7-57,7$ \\
Overweight/obesity & 48,2 & - \\
Male sex & 33,9 & $31-36,8$ \\
Smoking & 17,8 & - \\
$>60$ years & 31,6 & $28,8-34,4$ \\
Hyp. $>140 / 90 \mathrm{mmHg}$ & 14,4 & $12,3-14,4$ \\
>160/95mmHg & 7 & $5,4-8,6$ \\
Glucose $>126 \mathrm{mg} / \mathrm{dL}$ & 5,6 & $4,2-7$ \\
Cholesterol $>240 \mathrm{mg} / \mathrm{dL}$ & & \\
\hline Hyp - hypertension & & \\
\hline
\end{tabular}


Blood pressure recordings were performed on the same day, and 2 blood pressure values were considered: a) $>140 / 90 \mathrm{mmHg}$, which was observed in $31.6 \%$ of the population studied, and b) $>160 / 95 \mathrm{mmHg}$, which was used in an attempt to attenuate the effect of regression in the mean and in these conditions the percentage observed was $14.4 \%$. Once again, a significant increase in the incidence of hypertension was observed as age increased (fig. 2).

Glycemic levels $>126 \mathrm{mg} / \mathrm{dL}$ and total cholesterol levels $>200 \mathrm{mg} / \mathrm{dL}$ were observed, maintaining the same profile of the preceding risk factors, ie, an increase in percentage as age increased (fig. 3 ).

\section{Discussion}

A sedentary lifestyle is highly prevalent in our environment even among the younger population. Duncan et al ${ }^{18}$ had already reported a $47 \%$ incidence of sedentary lifestyle in the city of Porto Alegre in 1993.

We observed that $54.7 \%$ of the population studied was overweight or obese, $18.6 \%$ being obese. In 1991, the Ministry Health reported that approximately $32 \%$ of Brazilian adults were overweight to a certain extent (body mass index $>25){ }^{19}$. Cervato et al ${ }^{20}$ reported $38 \%$ obesity in the municipality of São Paulo. Duncan et al ${ }^{18}$ reported 18\% obesity in the city of Porto Alegre.

According to data collected in the present study (tab. I), in the State of Rio Grande do Sul in the year 2000, smokers represented $33.9 \%$ of the population. In 1993, the Federal Health Authority reported that smokers accounted for

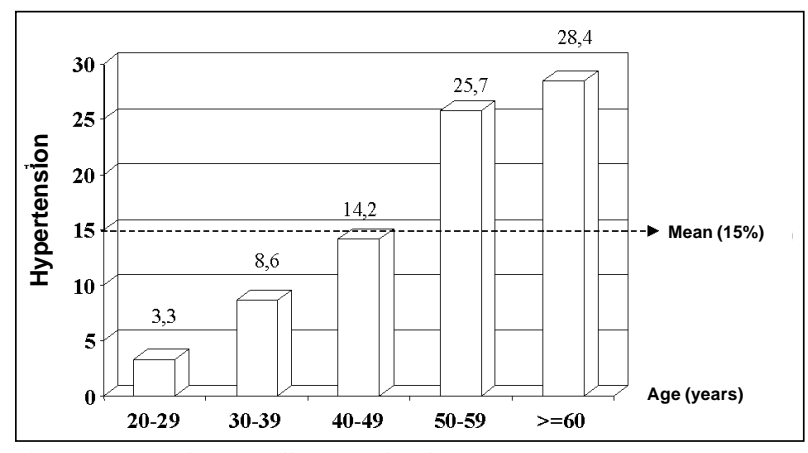

Fig. 2 - Hypertension according to age bracket.

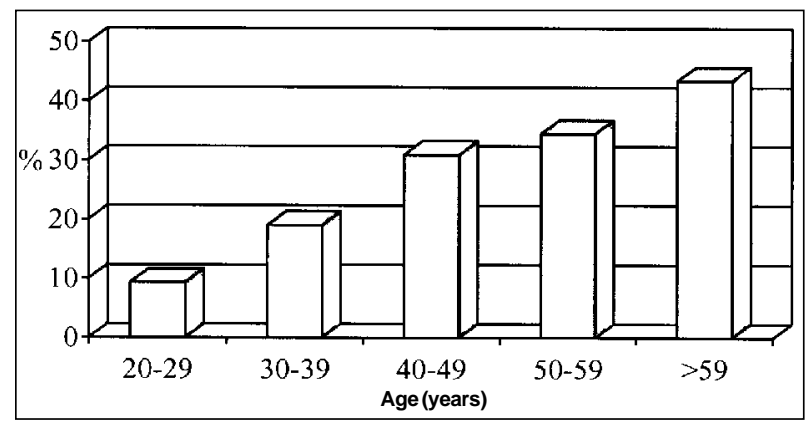

Fig. 3 - High cholesterol levels according to age bracket $(n=985)$; $p<0.001$.
$23.9 \%$ of the Brazilian population, considering a population that included the age of 5 years ${ }^{19}$. In 1995 , the World Health Organization (WHO) reported that adult smokers in Brazil represented $32.5 \%$ of the population, and, according to Duncan et al ${ }^{18}$, they represented $40 \%$ of the population in the city of Porto Alegre. It seems that no reduction occurred in the number of smokers; according to the report of the Federal Health Authority ${ }^{19}$, the ex-smokers represented $23.9 \%$, and in our present study they represented $23.3 \%$ of the population studied.

In a study carried out in the city of Porto Alegre, Fuchs ${ }^{21}$ reported a $12.6 \%$ incidence of systemic arterial hypertension when blood pressure values $>140 / 90 \mathrm{mmHg}$ were considered as hypertensive, and an incidence of $19.2 \%$ when blood pressure values $>160 / 95 \mathrm{mmHg}$ were considered for blood pressure normalized by the use of antihypertensive drugs. In our study, when blood pressure values $>160 / 95 \mathrm{mmHg}$ were established to characterize systemic arterial hypertension, we obtained a $14.4 \%$ incidence of hypertension. As already explained, this other maximum blood pressure value was an attempt to attenuate the effect of the regression to the mean, because blood pressure measurement was performed twice on the same day. We considered values $>140 /$ $90 \mathrm{mmHg}$ as systemic arterial hypertension, with an incidence of $31.6 \%$; a clear increase in the incidence of systemic arterial hypertension was observed as age increased. The $\mathrm{WHO}^{22}$ reported a $15 \%$ prevalence of systemic arterial hypertension for Brazilian adults of both sexes; Yunis and $\mathrm{Krob}^{23}$ found a wide variation (from $5 \%$ to $40 \%$ ), depending on the region and population subgroups analyzed. Duncan et al ${ }^{18}$ in the city of Porto Alegre found an incidence of $14 \%$. Achutti et al ${ }^{24}$ reported a $50 \%$ incidence of systemic arterial hypertension for adults older than 50 years; in our study, considering that same age bracket, we found an incidence of $54.1 \%$. In a study carried out in the city of São Paulo, Lotufo ${ }^{25}$ found an incidence of $15.5 \%$ of hypertensive males and $7.8 \%$ of hypertensive females; in our study, of the total of $15 \%, 47.3 \%$ were hypertensive males and $52.7 \%$ hypertensive females. James et a ${ }^{26}$ reported a higher incidence of systemic arterial hypertension in males than in females.

According to the Ministry of Health ${ }^{19}$, the prevalence of diabetes mellitus in Brazil adjusted for age and considering the value of $120 \mathrm{mg} / \mathrm{dL}$ was $7.6 \%$ in adults aged from 30 to 69 years. In our study, glycemias between 110 and $125 \mathrm{mg} / \mathrm{dL}$ were found in $8.1 \%$ of the population studied, and $>126 \mathrm{mg} / \mathrm{dL}$ were found in $7 \%$. Increases in glycemia were observed with increases in age. In the city of Porto Alegre, Duncan et al ${ }^{18}$ reported an $8.89 \%$ prevalence of diabetes mellitus. Cervato et al ${ }^{20}$ reported a lower percentage of diabetes mellitus in adults older than 20 years $(5 \%)$.

Figure 3 shows the behavior of the percentages of total cholesterol levels $>200 \mathrm{mg} / \mathrm{dL}$ according to the different age brackets; the increase in the percentages with age is evident and statistically significant. Table I shows the percentage found for total cholesterol levels $>240 \mathrm{mg} / \mathrm{dL}$ (5.6\%, confidence interval: 4.2-7.0). In his study, Lotufo 25 reported the following percentages of high total choles- 
terol levels in 3 different Brazilian cities: $9 \%$ in the city of São Paulo; $8.6 \%$ in the city of Salvador; and $11.7 \%$ in the city of Porto Alegre.

It was clear that the percentages of hypertension, of overweight, of high glycemia, of high cholesterol levels, and of sedentary lifestyle significantly increased in the more advanced ages. The percentage of smokers also increased with age. Therefore, we will have to face a growing number of patients with cardiovascular diseases, among which is coronary artery disease, because the elderly population in Brazil progressively increases ${ }^{1}$.

Cardiovascular diseases, especially coronary artery disease, are the $5^{\text {th }}$ cause of death in the whole world, and they are estimated to be the leading cause of death by the year 2020 , if no preventive measures are taken ${ }^{27}$. In round numbers, they account for $34 \%{ }^{28,29}$ of the causes of death, with similar data for the entire American continent. In Brazil, cardiovascular diseases account for 300,000 deaths per year or 820 per day ${ }^{30}$. In 22 nations of the American continent, mortality due to cardiovascular diseases continues to be high and very similar, with a predominance in the female sex ${ }^{27,29}$.

In the United States, deaths due to cardiovascular diseases are distributed as follows ${ }^{31}$ : coronary artery diseases, $53 \%$; other heart diseases, $26 \%$; cerebral stroke, $15 \%$; arterial diseases, $5 \%$; others, $1 \%$. Mortality due to heart disease has been decreasing since $1960^{32}$, but coronary artery disease continues to lead as a cause of death for both sexes.

In the city of Porto Alegre, according to the SIM report ${ }^{33}$ of the municipal office, the distribution of the deaths due to cardiovascular diseases is as follows: ischemic heart disease, $40.1 \%$; cerebral stroke, $31 \%$; heart failure, $13.2 \%$; other heart and vascular diseases: $15.7 \%$.

On the other hand, the report ${ }^{34}$ on the trend of the risk of death due to cardiovascular disease in 11 capitals selected from 1980 to 1998 shows that the coefficient of mortality in all Brazilian regions has decreased for both sexes and all ages as compared with those of the years 1979, 1987, and 1996. This may probably be due to the advanced therapeutic interventions in acute ischemic syndromes, the therapeutical tools available in cardiology, and the remarkable advances in the interventional therapeutics. We still do not have a similar reduction in morbidity due to heart diseases, even though national data are lacking.

According to reports of the Ministry of Health based on statistical data of the United Health System (SUS) in $1994^{35}$, the 3 major diseases leading to death in Brazil are as follows: myocardial infarction, cerebral stroke, and heart failure, showing the relevance of the morbidity of the cardiovascular diseases.

In Brazil, ischemic heart disease accounts for $1 / 3$ of the deaths due to cardiovascular diseases, suggesting that morbidity due to coronary artery disease is high. The morbidity of ischemic heart disease is so significant that, in the United States, only $5 \%$ of the population may be considered at low risk for ischemic heart disease, if we consider ${ }^{28}: 1$ ) total cholesterol below $200 \mathrm{mg} / \mathrm{dL}$; 2) systolic and diastolic blood pressure levels below $120 \mathrm{mmHg}$ and $80 \mathrm{mmHg}$, respectively; 3) nonsmoker; 4) no familial antecedents of myocardial infarction or of diabetes mellitus.

In severe coronary artery disease, $40 \%$ of the patients die within the first 30 days, according to the American Heart Association ${ }^{28}$ and $20 \%$ of the patients die suddenly with that type of coronary artery impairment. Patients with severe coronary artery disease who survive a first heart attack have a several times greater risk of dying within the following 5-10 years as compared with individuals without that antecedent.

In Brazil, we lack complete data on those parameters. But data already gathered in several cities and regions ${ }^{3,6-15,21,24-64}$ support the hypothesis that coronary artery disease may have the same behavior in regard to morbidity, because data on mortality in the entire country are similar. Our findings about the prevalence of risk factors in the state of Rio Grande do Sul (tab. I) suggest the relevance that the morbidity of coronary artery disease may have in our environment. With health programs for the population explaining and fighting the risk factors, we will be able to decrease their prevalence and reach effective and favorable results in the struggle against morbidity due to coronary artery disease.

We can state that this study reflects the reality of the prevalence of the risk factors for coronary artery disease in the State of Rio Grande do Sul. Our study has a clinical plan based on well-documented epidemiological studies, and it stresses the actual value of the risk factors assessed for coronary artery disease. It was also characterized by a wide scope, covering the entire state of Rio Grande do Sul. The only conscious bias was not dividing the population into rural and urban areas, but most of the study municipalities in the State of Rio Grande do Sul have this representation inside their own structure. Therefore, if we carry out similar studies in all Brazilian states, we will be able to develop serious and comprehensive programs of primary and secondary prevention for coronary artery disease.

With the increase in mean survival of the population, chronic and degenerative diseases will be more and more present. The best treatment for the major chronic and degenerative disease, ischemic heart disease, is prevention, which is achieved by fighting the risk factors. The best way to assess our management of the risk factors for coronary artery disease is through health programs comparing the results based on actual percentages of prevalence.

\section{Acknowledgments}

We thank FAPIC (Fundo de Apoio a Pesquisa of IC/ FUC) and SBC/FUNCOR. 


\section{References}

1. Gus I, Zielinsky P. As Cardiopatias no Brasil. In: Ferreira C; Póvoa R. Cardiologia para o Clínico Geral. Rio de Janeiro: Atheneu, 1999: 131-43.

2. $27^{\text {th }}$ Bethsda Conference - Matching the intensity of risk factor management with the hazard for coronary disease events. J Am Coll Cardiol 1996; 27: 957-1047.

3. Shimoda M, Sugayama S, Kim C, Ebaid M. Orientação Familiar preventiva: aspectos genéticos das doenças cardiovasculares e perspectivas futuras. Rev Soc Cardiol Estado de São Paulo 1996; 6: 623-22.

4. Ockene IS, Miller NH. Cigarette smoking, cardiovascular disease, and stroke. A statement for healthcare professionals from the American Heart Association. Circulation 1997; 96: 3243-7.

5. Jee SH, Suh I, Kim IS, Appel LJ. Smoking and atherosclerotic cardiovascular disease in men with low levels of serum cholesterol: the Korea Medical Insurance Corporation Study. JAMA 1999; 282: 2149-55.

6. Steenland K, Thun M, Lally C, et al. Environmental tobacco smoke and coronary heart disease in the American Cancer Society CPS-II cohort. Circulation 1996; 94: 622-8.

7. Kawachi I, Colditz GA, Speizer FE, et al. A prospective study of passive smoking and coronary heart disease. Circulation 1997; 95: 2374-9.

8. Law MR, Morris JK, Wlad NJ. Environmental tobacco exposure and ischaemic heart disease: an evaluation of the evidence. Br Med J 1997; 315: 973-80.

9. He J, Vupputri S, Allen K, et al. Passive smoking and the risk of coronary heart disease a meta-analisys of epidemiologic studies. N Engl J Med 1999; 340: 920-6.

10. Fein F, Scheuer J. Heart disease in diabetes mellitus: theory and practice. In: Rifkin H, Port D (Eds). Diabetes Mellitus. New York: Elsever, 1990: 812-23.

11. Gould AL, Rossoouw JE, SantanelloNC, Heyse JF, Furberg ED. Cholesterol reduction yields clinial benefit: impact of stastin trials. Circulation 1998; 97: 946-52.

12. The six report of the Joint National Committee on prevention, detection, evaluation, and treatment of high blood pressure. Arch Intern Med 1997; 157: 2413-46.

13. Wilking SVB, Belanger AJ, Kannel WB, D'Agostinho RB, Steel K. Determinants of isolated systolic hypertension. JAMA 1988; 260: 3451-5.

14. Collins R, Pepo R, MacMahon S, et al. Blood Pressure, stroke, and coronary heart disease. Part 2, short-term reductions in blood pressure: overview of randomized drug trials in their epidemiological context. Lancet 1990; 335: 827-38.

15. Powell KE, Thompson PD, Caspersen CJ, Kendrick JS. Physical activity and the incidence of coronary heart disease. Annu Rev Public Health 1987; 8: 253-87.

16. Leon AS, Connett J, Jacobs DR Jr, Rauramaa R. Laisure-time physical activity levels and risk of coronary heart disease and death: the Multiple Risk Factor Intervention Trial. JAMA 1987; 258: 2388-95.

17. Paffeenberger Jr RS, HydeRT, Wing AL, Lee IM, Jung DL, Kampert JB. The association of changes in physical-activity level and other lifestyle characteristics with mortality among men. N Engl J Med 1993; 328: 538-45.

18. Duncan BB, Schimidt MI, Polanczyk CA, Hormrich CS, Rosa RS, Achutti AC. Risk Factors for non-communicable diseases in a metropolitan area in the south of Brazil: prevalence and simultanelty. Rev Saúde Pública 1993; 27: 43-8.

19. Brasil. Ministério da Saúde. Estudo multicêntrico sobre a prevalência do diabetes mellitus no Brasil/Multicenter study about the prevalence of diabetes mellitus in Brazil. Brasilia, DF. Ministério da Saúde, 1991: 32p.

20. Cervato AM, Mazzili RN, Martins IS, et al. Dieta habitual e fatores de risco para doenças cardiovasculares. Rev Saúde Pública 1997; 31: 227-35.

21. Fuchs FD. Hipertensão arterial sistêmica. Epidemiologia e prevenção. Arq Bras Cardiol 1994; 63: 443-44.

22. Guidelines for the management of mild hypertension. Memorandum from a World Health Organization/International Society of Hypertension. Meeting Guidelines Sub-committee. J Hypertension 1993; 11: 905-18.

23. Yunis C, Krob HA. Status of health and prevalence on hypertension in Brazil. Ethn Dis, 1998; 8: 406-12.

24. Achutti A, Achutti VR. Fatores de risco para aterosclerose. Elementos para descrição da situação no Rio Grande do Sul. Arq Bras Cardiol 1994; 63: 427-31.

25. Lotufo PA. Epidemiologia da hipertensão arterial sistêmica no Brasil. In: SOCESP II - Cardiologia: Atualização e Reciclagem. São Paulo: Atheneu, 1996: 327-31.

26. James AS, de Almeida-Filho N, Kaufman JS. Hypertension in Brazil: a review of the epidemiological evidence. Ethn Dis 1991; 1: 91-8.

27. Murray CJK, Lopez AD. Global Burden of Disease Summary. Havard School of Public Health Organization, 1996.

28. Greenland P. Compendio de Cardiologia Preventiva 1. American Heart Association: São Paulo: EPUC - Editora de Publicações Científicas Ltda, 1994.

29. Cardiovascular and Cerebrovascular Disease in the Americas, 1996, and IHF publication Pan American Health Organization Data. FIAH Boletim. Dallas USA, 1996: 18 .

30. Lotufo PA. Epidemiologia das doenças cardíacas no Brasil: histórico, situação atual e proposta de modelo teórico. Rev Soc Cardiol Estado de São Paulo 1996; 6: 541-7.

31. Morbity and Mortality Chartbook on Cardiovascular, Lung and Blood Service. National Institute of Health, 1990.

32. Coronary heart disease mortality trends among whites and blacks - Appalachia and United States, 1980-1993. MMWR Morb Motal Wkly Rep 1998; 47: 1005.

33. Boletim Informativo. Sistema de Informação da Prefeitura Municipal de Porto Alegre. Porto Alegre-RS, 1996.

34. Relatório sobre a tendência do risco de morte por doença cardiovascular em 11 capitais selecionadas de 1980 a 1998. Laboratório de Análises de Dados Biomédicos-MS. Rio de Janeiro. FUNCOR, 2000.

35. Brasil. Ministério da Saúde. A saúde no Brasil, 1996. Ministério da Saúde. Brasília, DF, março 1997.

36. Vieira Neto OM. Níveis pressóricos normais. Rev Bras Hipertens 2000; 7: 303-7.

37. Nogueira A da R, Alves PM, de Miranda FR, Boechat NL. Cholesterol and other cardiovascular risk factors among employees of the Universidade Federal do Rio de Janeiro: prevalence and influence of social variables. Arq Bras Cardiol 1990; 55: $227-32$.

38. de Moraes AS, de Souza JM. Diabetes mellitus and ischaemic heart disease: casecontrol study. Rev Saúde Pública 1996; 30: 364-71.

39. Lotufo PA. Epidemiologia da Hipertensão Arterial Sistêmica no Brasil. In: SOCESP II - Cardiologia: Atualização e Reciclagem. São Paulo: Atheneu, 1996: 327-31.

40. Ramos LR, Santos FR, Marcopito LF. Morbidade e Mortalidade por Doenças Cardíacas em São Paulo. In: SOCESP II - Cardiologia: Atualização e Reciclagem. São Paulo: Atheneu, 1996: 1-4.

41. Gus I, Zaslavsky C. Fumo um importante fator de risco coronariano. Rev Soc Cardiol RS 1998; VI: 15-20.

42. Rabelo L, Novazzi JP, Martinez T. Aspectos preventivos no diabete melito com relação às doenças cardiovasculares. Rev Soc Cardiol Estado de São Paulo 1996; 6: 585-89.

43. Forti N, Diament J. Dislipidemia e prevenção primária da doença coronária aterosclerótica. Rev Soc Cardiol Estado de São Paulo 1996; 6: 610-6.

44. Diament J, Forti N. Dislipidemia e prevenção secundária da doença coronária aterosclerótica. Rev Soc Cardiol Estado de São Paulo 1996; 6: 617-22.

45. Issa JS. Fumo e doenças cardiovasculares: prevenção primária e secundária. Rev Soc Cardiol Estado de São Paulo 1996; 6: 590-5.

46. Issa JS, Aguiar FM, Giannini SD, et al. Influência do hábito de fumar na concentração de monóxido de carbono do ar expirado de moradores da cidade de São Paulo. Rev Soc Cardiol Estado de São Paulo 1995; 5(supl. B): 47.

47. Lotufo PA. A mortalidade precoce por doenças crônicas nas capitais de áreas metropolitanas do Brasil [Tese de Doutorado]. São Paulo: Faculdade de Saúde Pública da Escola Paulista de Medicina, 1996.

48. Issa JS, Francisco YA. Obesidade e doenças cardíacas: aspectos epidemiológicos e preventivos. Rev Soc Cardiol Estado de São Paulo 1996; 6: 558-63.

49. Moraes S, Souza JM. Diabetes mellitus e doença isquêmica do coração. comparação por sexo. Arq Bras Cardiol 1996; 66: 59-63.

50. Costa E. Across sectional survey of blood pressure in Rio Grande do Sul - Brazil [PhD Thesis]. Londres: University of London, 1981.

51. Consenso Brasileiro para uso da MAPA. Arq Bras Cardiol 1996; 67: 129-48.

52. Lotufo P. Doenças cardiovasculares no Brasil: porque altas taxas de mortalidade entre mulheres? Rev Soc Cardiol Estado de São Paulo 1996; 6: 667-71.

53. Fuchs FD, Moreira LB, Moraes RS, et al. Prevalência da hipertensão arterial sistêmica e fatores associados na população urbana de Porto Alegre: estudo de base populacional. Arq Bras Cardiol 1994; 63: 473-9.

54. Trindade I, Heineck G, Machado JR, et al. Prevalência da hipertensão arterial sistêmica na população urbana de Passo Fundo (RS). Arq Bras Cardiol 1998; 71: 1-4.

55. Luna RL. Hipertensão arterial: nova definição e tratamento atual. Vitrô Cardiol 1994; $1: 1-4$.

56. Ribeiro AB. Conceito, determinação e classificação da hipertensão arterial: In: Atualização em Hipertensão Arterial: Clínica, Diagnóstico e Terapêutica. São Paulo: Atheneu, 1996.

57. Gus I. Febre reumática aguda: epidemiologia, achados clínicos e laboratório de febre reumática aguda. Arq Bras Cardiol 1995; 65:321-5. 
58. Switcowsky R, Camargo PR, Tanaka AC, et al. Febre Reumática. In: SOCESP II Cardiologia: Atualização e Reciclagem. São Paulo: Atheneu, 1994: 429-46.

59. Switcowsky R. Profilaxia da febre reumática. Rev Soc Cardiol Estado de São Paulo 1993; 3: 17-9.

60. Oliveira JJ, Silva SR, Vigle J. Doença reumática. Arq Bras Cardiol 1997; 69: 69-76.

61. Secretaria da Saúde e do Meio Ambiente do Estado do Rio Grande do Sul. Estatísticas de Saúde - Mortalidade. Secretaria da Saúde e do Meio Ambiente do Estado do Rio Grande do Sul 1992; 18: 1-160.

62. Lessa I. Estudos Brasileiros sobre a Epidemiologia da Hipertensão Arterial.
Análise crítica dos estudos da prevalência. Ministério da Saúde. Fundação Nacional da Saúde. Centro Nacional de Epidemiologia. Informe Epidemiológico do SUS, 1993; II(3).

63. Haddad N, da Silva MB. Mortalidade por doenças cardiovasculares em mulheres em idade reprodutiva (15 a 49 anos), no Estado de São Paulo, Brasil, 1991 a 1995 Arq Bras Cardiol 2000; 75: 375-9.

64. Fórnes NS, Martins IS, Herman M, et al. Food frequency consumption and lipoproteins serum levels in the population of an urban area, Brazil. Rev Saúde Pública 2000; 34: 380-7. 